\title{
Z Kuşağı YouTube Kullanım Motivasyonları
}

\author{
Aysun Köktenera, ${ }^{\mathrm{a}}$, And Algülc
}

\section{Özet}

'Network' gençleri olarak ifade edilen Z Kuşağı, YouTube'u son derece aktif kullanarak sosyalleşmekte, neredeyse tüm iletişimlerini dijital teknolojik aletlerle kurarak adeta yüksek teknoloji ile var olmaktadır. Hızın önem kazandığı tüketim toplumu içine doğan $\mathrm{Z}$ Kuşağı, toplumsal pratiklerin etkisiyle kendi dünyalarını yaratarak, kuşaklararası değer değişimini fark edilebilir bir şekilde ortaya koymaktadırlar. Bu kapsamda, rastgele örnekleme metodu kullanılarak, Z Kuşağı YouTube kullanıcılarının kullanım motivasyon farklılığı olup olmadığını ortaya çıkarmak amacıyla 654 katılımcıyla anket çalışması gerçekleştirilmiştir. Araştırmada, ilköğretim öğrencileri ile ortaöğretim öğrencilerinin YouTube kullanım motivasyonları ile haftalık ve günlük olarak YouTube'a erişim sağladıkları araçların farklılık gösterdiği ortaya çıkmıştır. İlköğretimdeki Z Kuşağı kullanıcılarının YouTube kullanım motivasyonu açısından akran olma durumunun önemli olduğu ve bu nedenle dijital medya okuryazarlığına ağırlık verilmesi gerektiği sonucuna varılmıştır.
Anahtar Kelimeler

YouTube

Z Kuşağ1

Motivasyon

Dijital Medya Okuryazarlığı

Makale Hakkında

Geliş Tarihi: 24.01.2020

Kabul Tarihi: 25.12.2020

Doi: 10.18026/cbayarsos.679505

\section{YouTube Use Motivations of Generation Z}

\section{Abstract}

Referred to as the "Network" teenagers, Generation Z socialize by using YouTube and communicating almost entirely by means of digital technological tools. Generation $\mathrm{Z}$ who were born into a consumption society in which speed gained importance, create their own world under the influence of social practices, thereby noticeably revealing the intergenerational change in values. Within this scope, some 654 respondents were surveyed by employing the method of random sampling in order to reveal whether there were differences in the use motivations Generation Z YouTube users. In the research, it turned out that YouTube use motivations of the primary school students and the secondary school students and the tools whereby they accessed YouTube weekly and daily differed. It was concluded that the state of being peers was significant in terms of the YouTube use motivations of primary school Generation $\mathrm{Z}$ users and that one should therefore concentrate on digital media literacy.
Keywords

YouTube

Generation Z

Motivation

Digital Media Literacy

\section{About Article}

Received: 24.01.2020

Accepted: 25.12.2020

Doi: 10.18026/cbayarsos.679505 


\section{Introduction}

The important historical events and social changes experienced in the society influence the values, attitudes, beliefs, and tendencies of individuals. Differences in the perceptions, communication, and behavior of people occur under this influence. The concept and theory of generations originated from these differences, which were categorized by sociologists. The time ranges occurring with economic and social movements worldwide were described as generations (Keleş, 2011: 129). Generations have attitudes and behaviors coordinating with each other under the impact of the year of birth they share, the changes in their environment, and the important historical transformations. Depending on their birth within the same period of time, these coordinating behaviors lead to the sharing of the same manners, ideas, values, and beliefs (Lissitsa \& Kol, 2016). They naturally differ from the behavioral patterns of the other generations. These behavioral differences cause significant distinctions among generations in their characters, working lives, and social lives. This has enabled the concept of generation to become a subject for research and studies in terms of many disciplines such as history, sociology, psychology, and management science.

When the historical development of the concept of generation is considered, it is observed that different definitions have been made by different disciplines. In addition, there occur diversities of distinctions of generations and definitions also by country and cultural differences in the studies carried out worldwide. While it was observed that the researchers expressed different dates, although partially, in their chronological classification of generations, it was seen that they reached a compromise in determining both the names of generations and their time ranges in the general sense (Taş et al., 2017: 1034). When the studies carried out are considered, it is seen that the generations are predominantly addressed as the Silent Generation, the Generation of Baby Boomers, Generation X, Generation Y, and Generation Z. Whilst the perceptions, expectations, and priorities of people, their perspectives on life and their behaviors varied depending on the concept of time, the fact that those born in close periods had similar qualities and that each generation had different qualities led to the intensification of researchers' interest in the concept of generation and the qualities of generations (Adigüzel et al., 2014).

YouTube use motivations of Generation Z, also called the Internet generation and intensively using the digital media, were examined in this study. Also expressed as the 'Network' teenagers, Generation $\mathrm{Z}$ socialize through the social media and exist with technology by communicating with the world by means of telephones and tablets. Generation $Z$, who were born into a consumption society where speed gained importance, are described as an impatient generation (Karahisar, 2013: 79). Resulting from speed, their impatience is also reflected in their character, lifestyle, and media use habits. In this line, since the perception and behavioral patterns of Generation $\mathrm{Z}$ do not form any homogeneous structure either, the YouTube use habits and motivations of the primary and secondary school students selected as the research sample were compared and evaluated individually.

\section{Generations and the Generational Theory}

The concept of generation refers to the people who were born in the same time range and who have been affected by the social, economic, cultural, and political events and prevailing values of the time when they live as well as to the communities that these people make up 
(Altuntuğ, 2012). The Turkish Language Institution takes period and year into consideration when defining a generation. It defines a generation as the community of those people who were born in almost the same years, who have shared the conditions of the same age and hence similar troubles and fates, and who have been responsible for similar duties (TDK, 2018). When considered in general, a community that consists of those people who were born in almost the same time ranges, who share similar value judgments, behaviors, and lifestyles, who have been shaped by the events and trends of a certain period, and who have the same thoughts and actions may be defined as a "generation" (Lower, 2008; Keleş, 2011: 131).

On the other hand, those researchers who think that it is not correct to classify and evaluate generations only in terms of the time when they were born state that the emotions, thoughts and experiences of the individuals who make up the community of generations should also be defined. According to these researchers, when a generation is considered, one should speak of the community of people with common sharings rather than the community of people born in certain time ranges because the communities of people born in the same country and in the same period may not display the same generational qualities (Arslan \& Staub, 2015: 6; Taş et al., 2017: 1035).

The theory of generational groupings or the theory of generations with a robust foundation in sociological theory was first suggested in the book entitled "On the Problem of Generations" and written in 1928 by Karl Mannheim - a German sociologist (Mannheim, 1952). Furthermore, the classification and discussions including the current generations first commenced with the classification whereby Inglehart divided the population into sections in 1977 and which he called "Generational Cohort Theory". According to this theory, it is put forward that the important historical events and social changes in the society influence the values, attitudes, beliefs, and tendencies of individuals and that the resulting intergenerational change in values acts slowly but has a deep impact in the long term (Inglehart, 2008). Later on, the theory of generations was theorized by addressing the qualities and characteristics of generations particularly in the case of the 18 generations that lived in America with the book published by Strauss and Howe (1991) and this theory was called "the Strauss-Howe Generational Theory" by some researchers about generations. According to this theory, many important historical events and social changes in every society may influence the value judgments, attitudes, behaviors, and tendencies of the individuals of that society. That's why it is suggested that the individuals who are born at a certain time and who are in the same age group display similar behavioral characteristics and that these behavioral characteristics may change with every new generation (Moss, 2010).

\section{Classification and Qualities of Generations}

The concept and classification of generation are the subjects of different interdisciplinary studies today and, according to the researchers, the classification and perception of generations vary by culture (Adigüzel et al., 2014: 170). In their study, Strauss and Howe (1991) state that the firm distinctions of generations are debatable but that the concept of generation covers an approximate time span of a score of years. According to the biological definition, which only takes year as the basis, it is expressed that generations are placed in each millennium at intervals of 20 to 25 years, whereas in the sociological definitions, 
generations are described as the groups who are born on certain dates and who have common values, beliefs, expectations, and behaviors as they have been influenced by common social, political, and economic events in the socialization process (Metin \& Kizıldağ, 2017: 342). Some 5 different generations have been defined since the 20th century, namely the Silent Generation, born between 1927 and 1945; the Generation of Baby Boomers (BB), born between 1946 and 1964; Generation X, born between 1965 and 1980; Generation Y, born between 1981 and 1999; and Generation Z, born in and after 2000 (Akdemir et al., 2013: 14; Çetin \& Karalar, 2016: 159; Özdemir, 2017).

When different sources are reviewed, it is seen that the time ranges about generations and the qualities of generations are not identical. For instance, in the USA, the Silent Generation are called "Founders" and the year 1920 is taken as the basis as their year of birth, while in Canada, the Silent Generation are called "the Elderly" and their year of birth commences from 1900. Likewise, Generation Y are positioned with those who were born in 1977-1994, 1980-1990 or 1981-1995 and Generation Z are classified to cover those who were born in 1990, 1993, and 1995 or in and after 1996 (Taylor, 2008: 7; Turner, 2015; Quintal et al., 2016; Priporas et al., 2017).

\subsection{The Silent Generation (1927-1945)}

This generation is comprised of those who were too young to attend the war during the years when World War II broke out. As they grew up during the hard days of the war and at a time when they were considered that they should not be seen under feet very much, this group is called "the Silent Generation". Also called 'the war generation' or 'the Greatest Generation' due to their contributions to World War II, this generation is known as "the Republican Generation" in Turkey (Karahasan, 2018: 24).

\subsection{The Generation of Baby Boomers (1946-1964)}

Baby Boomers, the post-war generation of change, are acknowledged as the representatives of ideologies, pleasure, and rebellion against order (Altuntuğ, 2012: 204). Also called "the Boom Generation" due to the increase in the birth rates, this generation is also referred to as 'the Sandwich Generation' since they look after first their children and then their aged parents in the same house (Metin \& Kızıldağ, 2017: 343). Nevertheless, the term "Baby Boomers" (those who were born in the period of a boom in the birth rate), used to define this age group in an article in Washington Post in 1977, was adopted worldwide. The most important feature that takes the BBs to a different point among all generations is that they are the architects of Generation '68, who have been made legendary. Generation '68 are the first generation who grew up with television and who realized that a television was an effective communication tool.

\subsection{Generation X (1965-1980)}

To revive the post-war capitalist system, a social state was built by implementing Keynesian policies, thereby creating an environment of welfare. This increase in welfare, which embraced every section, ended when its cost far exceeded the power of states and when the oil crisis experienced in the '70s caused the giant enterprises to undergo a bottleneck and it was replaced by liberal policies (Altuntuğ, 2012: 205). The negative cases concerned caused Generation X to grow up with troublesome processes (Metin \& Kizlldağ, 2017: 343). Most of 
them turned into independent and critical individuals and also drew attention with their attaching of importance to working as well as with their stubborn and patient working discipline (Karahasan, 2018: 25).

\subsection{Generation Y (1981-1999)}

Born between 1981 and 1999 and known as Millennials by many people, Generation Y are acknowledged as the first high technology generation (Gurău, 2012; Kraljević \& Filipović, 2017: 6). The starting point of Generation $Y$ is indeed the English word 'why'. Letter Y was considered appropriate owing to the structure of the individuals of this generation that questioned every concept or innovation they encountered (Özmen, 2018: 131). Generation Y are regarded as the early digital natives as they are more interested in the Internet and the social media (Bento et al., 2018). Although they are individualistic and consumerist, focus on momentary pleasures, and are distant from the sense of loyalty, they provide a profile which protects such concepts as sustainability, ethics, and social responsibility. Generation Y, a generation that is more impatient, more impetuous, more social, and more self-confident than the previous generations, also have different ways of using technology from those of the previous generations (Kuyucu, 2017: 868).

\subsection{Generation Z (after 2000)}

The members of Generation Z, who are just experiencing their childhood and adolescence, are referred to with many names such as the Internet generation, the new silent generation, the Google generation, the .com generation, the I-Generation or the Crystal Generation (Keleş, 2011: 132; Akdemir et al., 2013: 15; Adıgüzel et al., 2014: 161; Çetin \& Karalar, 2016: 162). The most significant difference which distinguishes Generation $Z$ from the others is that they live online, witness a period in which digital high technology is widely used and in which change is experienced very rapidly and in the form of breaks, and are the first generation that has integrated with the digital world (Priporas et al., 2017: 374; Taş et al., 2017: 1033).

When the ways and habits of media use by Generation Z - also called the 'Network' teenagers - are considered, it is observed that this generation intensively uses the digitallybased media. The research carried out reveals that Generation $\mathrm{Z}$ prefer being online and continually interactive (Özdemir, 2017: 60). They want to learn when they desire and under the conditions they determine. They like those activities which allow creativity; they do not accept passivity; and their long-term memory can become active through games, storification, and dreams rather than memorization (Yelkikalan et al., 2010: 502). The Zs, who are able to connect very easily with those who live anywhere worldwide, are expressed as a generation that is technology-dependent and impetuous, that has a good command of the Internet, that is creative, that has multiple attention and multiple decision-making skills, that wants everything quickly and consumes everything instantly, that can perform more than one task simultaneously, that prefers trial and error, that has developed sensory abilities, that prefers the Internet technology, and that attaches more importance to visuality rather than written texts (Çubukcu \& Bayzan, 2013: 151; Mercimek et al., 2016: 68). It is stated that the Zs, who get bored quickly with everything they regard as unnecessary details, are impatient but can have as much knowledge about any subject they like as an expert can (Karahisar, 2013: 79). 
The Zs, who are more equipped than the other generations in educational and economic terms, experience time very fast and want to fit in many things into this speed. One of the common qualities of the teenagers in this age group is their multi-screen skills and their motives for performing many tasks simultaneously. As a result of the research, in which the behavior of performing more than one action simultaneously such as studying while eating and snacking while shopping was markedly observed, it was determined that Generation Z in this age range felt a day as being more than 24 hours.

\section{Media Use Habits of Generation $\mathrm{Z}$ and YouTube}

The ways of audio-visual sharing have increased extraordinarily upon the development of new communication media and the increase in the interest in information and communication technologies by every section. An individual has hardly any difficulty in accessing information by means of these ways of sharing. These developments enhance the power of the social media and introduce a new dimension to the concept of socialization (Akyazı \& Ünal, 2013: 5; Sarsar \& Engin, 2015: 167). Together with the conventional one, the social media have quite comprehensive content which encompasses the global changes and developments concerning a good lifestyle for people, social responsibility, national problems, and the cultures and policies of the other societies in the world. In this context, the media have a significant place in shaping individuals' world views, perceptions, and attitudes (Eshleman \& Bullcroft, 2009). In parallel with the development of technology, digital hardware and the Internet technology have become part of everyday life. This development has also been reflected in media use habits and daily newspapers have begun to leave houses (Somyürek, 2014: 66). In the research performed in 2017, it turned out that the teenagers aged between 14 and 17 years and acknowledged as Generation $\mathrm{Z}$ tended to abandon the conventional media tools. When the media use habits are considered, it is seen that Generation Z, who use the Internet for the social media, games, and entertainment the most, watch serials on TV the most. On the other hand, the rate of reading a newspaper every day is 9 per cent. In this respect, Generation $\mathrm{Z}$ can also be evaluated as screen addicts. Today a second screen concept is expressed for this generation, who are considerably intertwined with screens. While watching something in front of "the first screen" such as a TV or a video, the same person can simultaneously interact with his/her other devices, such as a smart phone and a tablet, too and watches YouTube for two to four hours per day on average (Özdemir, 2017: 62; Taş et al., 2017: 1033).

YouTube, the favorite social media platform of Generation $\mathrm{Z}$, has become a medium which is also used as an archive tool in addition to the social media; in which it is seen that more than half of the content is composed of television serials, football matches, and music videos when the videos in the list of the most popular videos are examined; which has been enriched together with user generated contents; and which is used for many different purposes. The access to the performances on YouTube, which allows a user to be a viewer only or, if he/she desires, a producer easily; into which videos of 100 hours are uploaded per minute; and in which a billion users watch videos for 6 billion hours per month, at any moment, anywhere, and at an extraordinarily economical cost (Çomu, 2012: 73; Thorson et al., 2013: 441; Çetin \& Bel, 2014: 67; Bonander \& Marsh, 2015: 453) increases the interest of Generation $Z$ in YouTube. YouTube ranks second as a search engine after Google and has a very fast rise. With $97 \%$, YouTube also became the medium that the children aged between 7 and 16 years 
liked the most in the research report Teknosa prepared for the Summit of Digital Heels in 2016 (Tunçalp, 2017). In the data of 2018 by US-based Pew research company, it is seen that $85 \%$ of the teenagers in the USA preferred YouTube - a video sharing platform (BBC, 2018).

The role models of Generation Z, who reveal their own lives through YouTube and "Vlogging" (video blogging), are their peers on YouTube and most of them imagine opening their own channel and becoming a celebrity on YouTube one day. In the research performed, it is stressed that Generation $\mathrm{Z}$ are continually sharing something in the social media and are particularly dissatisfied with videos (Türk, 2013). Issa and Isaias (2016: 593) allege that Generation $\mathrm{Z}$ are obsessive about obtaining the latest information and skills by using technology. In the research by Klobas et al. (2018) on YouTube use habits, it was concluded that the obsessive use of YouTube both might lead to a decrease in the academic motivation and had risks in those with anxiety.

Despite the availability of no adequate field research on the obsessive use of YouTube yet, the presence of Generation $\mathrm{Z}$ in this digital platform mostly creates the perception of "defenseless children in an unlimited world" in adults' eyes. It is mentioned that with this perception and as children are continually using the digital media, $77 \%$ of the adults are afraid of the use of children via the digital media, that $13 \%$ of them worry that they are psychologically negatively affected by the contents or will be exposed to cyber bullying, and that $10 \%$ of them worry that they have become addicted to the digital media (Tunçalp, 2017).

\section{Research}

The study aims to reveal whether there are differences in the use motivations of Generation $\mathrm{Z}$ YouTube users and what the consequences of this usage are. A literature review was carried out regarding the influencing YouTube usage motivations and 58 items were determined. In this context, some 654 respondents included in Generation Z were surveyed in February 2018 by employing the method of random sampling in order to reveal the YouTube use motivations.

Research question: "Are there any differences among the YouTube use motivations of Generation Z users? By means of what tool and how long do Generation Z users use YouTube weekly and daily the most? And what kind of a relationship is there between the use motivations of Generation $\mathrm{Z}$ users and their demographic characteristics?"

Within this scope, the research hypotheses are as follows:

Hypothesis 1: The most significant effect on the YouTube use motivations of the primary school students is the state of being peers.

Hypothesis 2: Digital media literacy is important for Generation Z primary school students.

Those outstanding items of the studies within the scope of the literature on the YouTube use motivations of Generation $\mathrm{Z}$ were addressed in the survey questions. As a result of the reliability test done, it was observed that Cronbach's alpha value turned out to be 0.965 . The alpha value obtained shows that the study is completely reliable. When the factor analyses of the primary and secondary school students in Generation $\mathrm{Z}$ were made, it was determined that there were twelve factors for the primary school students and nine factors for the secondary school students (Picture 1 and 2). 
When Picture 1 was considered, it was discovered that the Generation Z primary school students used YouTube for publicity and self-actualization, to reach information and alternative information, for entertainment, for socialization, for social interaction, to interact by discussing, for the appeal of access speed, to generate information and for self-expression to those who left comments, for the feature of the indexing of YouTube contents, to form a reliable relationship, and to access the rich content, respectively.

When Picture 2 was considered, it was established that the Generation Z secondary school students used YouTube to reach information and alternative information, for publicity and self-actualization, to obtain economic utility, for socialization and social interaction, for educational purposes, for self-expression by leaving comments, to encourage purchasing, for the appeal of access speed, and for entertainment, respectively.

\begin{tabular}{|c|c|c|c|}
\hline & Total & $\begin{array}{l}\text { Percentage } \\
\text { of } \\
\text { Variance }\end{array}$ & $\begin{array}{l}\text { Cumulative } \\
\text { Percentage }\end{array}$ \\
\hline F1. The factor "Using YouTube for publicity and self-actualization" & 17.724 & 30.041 & 30.041 \\
\hline $\begin{array}{l}\text { F2. The factor "Using YouTube to reach information and alternative } \\
\text { information" }\end{array}$ & 6.629 & 11.235 & 41.277 \\
\hline F3. The factor "Using YouTube for entertainment" & 4.264 & 7.226 & 48.503 \\
\hline F4. The factor "Using YouTube for socialization" & 3.503 & 5.937 & 54.440 \\
\hline F5. The factor "Using YouTube for social interaction" & 3.026 & 5.129 & 59.569 \\
\hline F6. The factor "Using YouTube to interact by discussing" & 2.128 & 3.607 & 67.916 \\
\hline F7. The factor "The appeal of YouTube access speed" & 1.922 & 3.258 & 71.175 \\
\hline F8. The factor "Using YouTube to generate information" & 1.831 & 3.103 & 74.278 \\
\hline $\begin{array}{l}\text { F9. The factor "Using YouTube for self-expression to those who leave } \\
\text { comments" }\end{array}$ & 1.497 & 2.537 & 76.814 \\
\hline F10. The factor "The feature of the indexing of YouTube contents" & 1.341 & 2.273 & 79.087 \\
\hline F11. The factor "Using YouTube to form reliable relationships" & 1.277 & 2.165 & 81.252 \\
\hline F12. The factor "Using YouTube to access the rich content" & 1.151 & 1.950 & 83.203 \\
\hline
\end{tabular}

Picture 1. Extraction Sums of Squared Loadings for Primary School Students.

\begin{tabular}{lrrr}
\hline & Total & $\begin{array}{l}\text { Percentage } \\
\text { of } \\
\text { Variance }\end{array}$ & $\begin{array}{l}\text { Cumulative } \\
\text { Percentage }\end{array}$ \\
\hline $\begin{array}{l}\text { F1. The factor "Using YouTube to reach information and alternative } \\
\text { information" }\end{array}$ & 20.414 & 34.599 & 34.599 \\
\hline F2. The factor "Using YouTube for publicity and self-actualization" & 6.931 & 11.747 & 46.347 \\
\hline F3. The factor "Using YouTube to obtain economic utility" & 2.449 & 4.152 & 50.498 \\
\hline F4. The factor "Using YouTube for socialization and social interaction" & 1.882 & 3.190 & 53.689 \\
\hline F5. The factor "Using YouTube for educational purposes" & 1.766 & 2.993 & 56.682 \\
\hline F6. The factor "Using YouTube for self-expression by leaving comments" & 1.547 & 2.621 & 59.304 \\
\hline F7. The factor "Using YouTube to encourage purchasing" & 1.310 & 2.221 & 61.525 \\
\hline F8. The factor "The appeal of YouTube access speed" & 1.290 & 2.187 & 63.711 \\
\hline F9. The factor "Using YouTube for entertainment" & 1.112 & 1.885 & 65.596 \\
\hline
\end{tabular}

Picture 2. Extraction Sums of Squared Loadings for Secondary School Students.

The relationship between the tool whereby Generation Z primary school students accessed YouTube and the duration of their daily use is stated below:

Of the respondents, 35.5\% stated that they used YouTube by means of a mobile device for less than an hour per day, $32.9 \%$ for an hour to 3 hours per day, 13.2\% for 3 to 5 hours per day. $27 \%$ of them stated that they used YouTube by means of a tablet for less than an hour per day, $27 \%$ of them for an hour to 3 hours per day. $29.3 \%$ of them stated that they used YouTube by means of a laptop for less than an hour per day, $20 \%$ of them for an hour to 3 hours per day. $19.2 \%$ of them stated that they used YouTube by means of a desktop for less 
than an hour per day. 32.4\% of them stated that they used YouTube by means of the smart televisions which could connect to the Internet for less than an hour per day, $12.2 \%$ of them for an hour to 3 hours per day (Graph 1).

The relationship between the tool whereby Generation Z secondary school students accessed YouTube and the duration of their daily use is stated below:

Of the respondents, $41.1 \%$ stated that they used YouTube by means of a mobile device for less than an hour per day, 39\% for an hour to 3 hours per day. $16.1 \%$ of them stated that they used YouTube by means of a tablet for less than an hour per day. $27.3 \%$ of them stated that they used YouTube by means of a laptop for less than an hour per day, 15.7\% of them for an hour to 3 hours per day. $18.2 \%$ of them stated that they used YouTube by means of a desktop for less than an hour per day. $23.9 \%$ of them stated that they used YouTube by means of the smart televisions which could connect to the Internet for less than an hour per day (Graph 2).

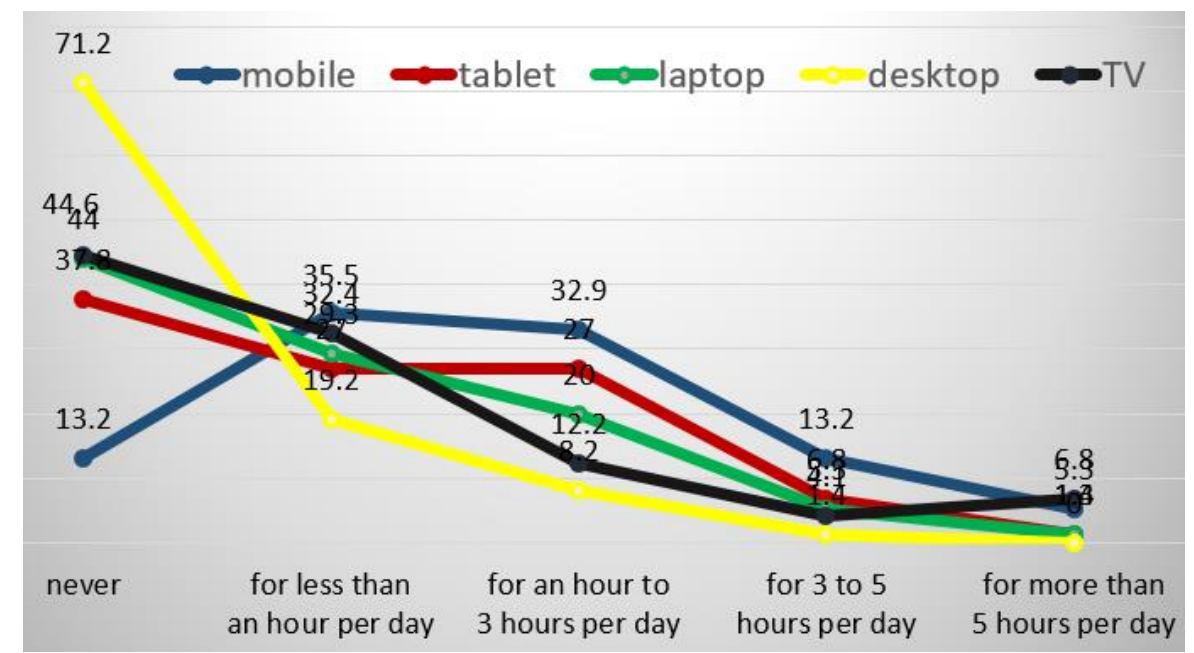

Graph 1. The Relationship between the Tool whereby Generation Z Primary School Students accessed YouTube and the Durations of their Daily Use.

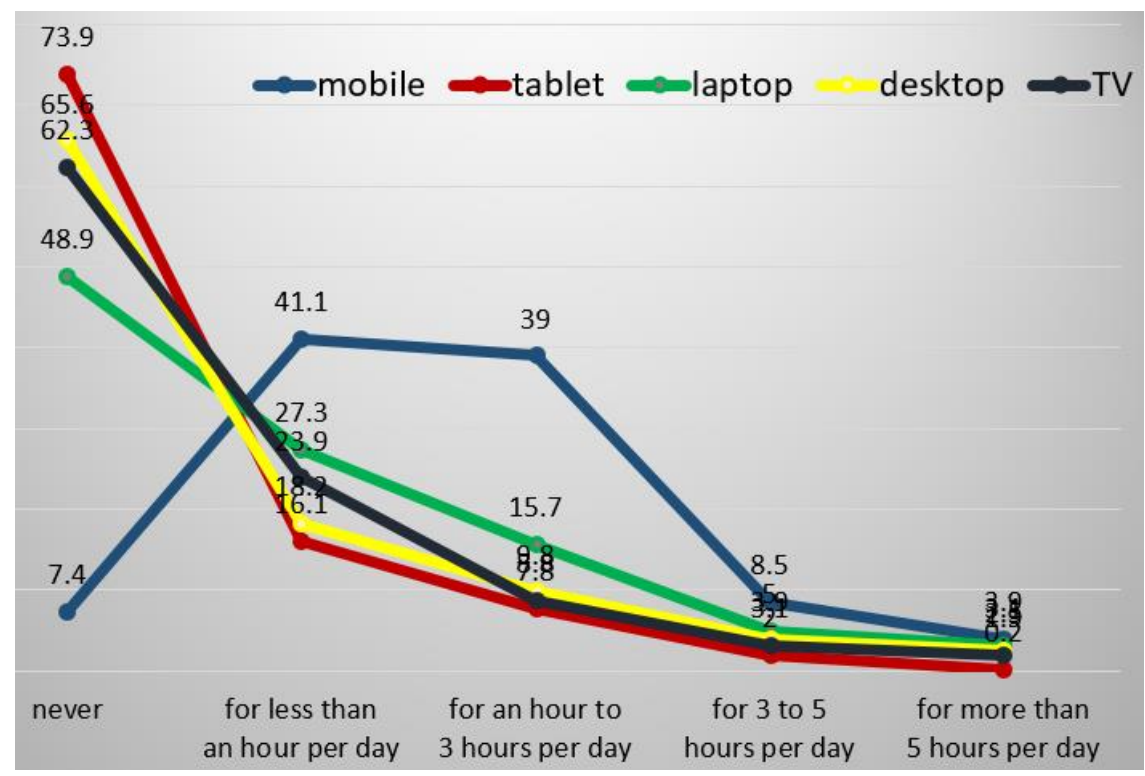

Graph 2. The Relationship between the Tool whereby Generation Z Secondary School Students accessed YouTube and the Durations of their Daily Use. 
The relationship between the tool whereby Generation $\mathrm{Z}$ primary school students accessed YouTube and the frequencies of their weekly use is stated below:

Of the respondents, $21.3 \%$ stated that they used YouTube by means of a mobile device for a day to 2 days per week, $17.3 \%$ for 3 to 4 days per week, $14.7 \%$ for 5 to 6 days per week and $30.7 \%$ on each day of the week. Of the respondents, $25 \%$ stated that they used YouTube by means of a tablet for a day to 2 days per week, $12.5 \%$ for 3 to 4 days per week, $13.9 \%$ on each day of the week. Of the respondents, $23 \%$ stated that they used YouTube by means of a laptop for a day to 2 days per week, $14.9 \%$ for 3 to 4 days per week, $9.5 \%$ for 5 to 6 days per week, and $9.5 \%$ on each day of the week. Of the respondents, $13.9 \%$ stated that they used YouTube by means of a desktop for a day to 2 days per week. Of the respondents, $32.4 \%$ stated that they used YouTube by means of the smart televisions which could connect to the Internet for a day to 2 days per week, $12.7 \%$ on each day of the week (Graph 3).

The relationship between the tool whereby Generation Z secondary school students accessed YouTube and the frequencies of their weekly use is stated below:

Of the respondents, $26 \%$ stated that they used YouTube by means of a mobile device for a day to 2 days per week, $15.8 \%$ for 3 to 4 days per week, $13.2 \%$ for 5 to 6 days per week and $39 \%$ on each day of the week. Of the respondents, $15.5 \%$ stated that they used YouTube by means of a tablet for a day to 2 days per week. Of the respondents, $25.4 \%$ stated that they used YouTube by means of a laptop for a day to 2 days per week, $11.7 \%$ for 3 to 4 days per week, $10.5 \%$ on each day of the week. Of the respondents, $16.2 \%$ stated that they used YouTube by means of a desktop for a day to 2 days per week, $10.3 \%$ on each day of the week. Of the respondents, 19.1\% stated that they used YouTube by means of the smart televisions which could connect to the Internet for a day to 2 days per week (Graph 4).

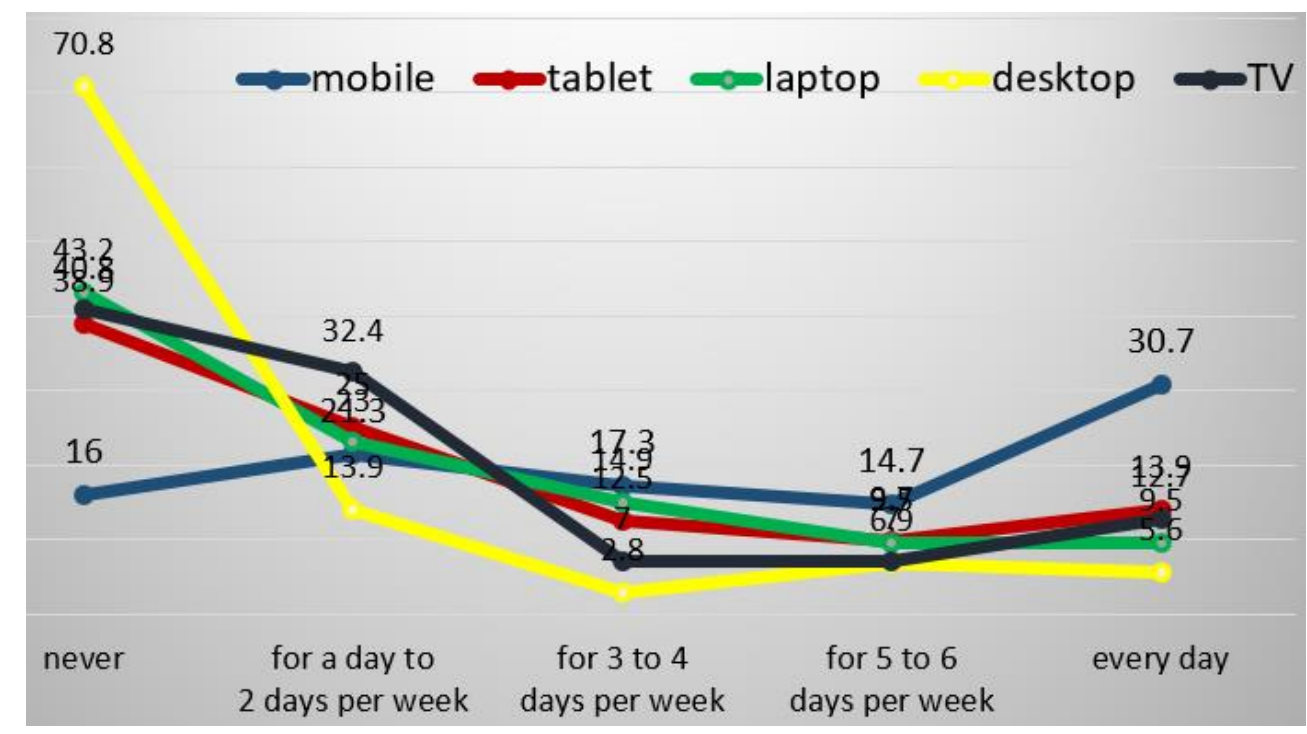

Graph 3. The Relationship between the Tool whereby Generation Z Primary School Students accessed YouTube and the Frequencies of their Weekly Use. 


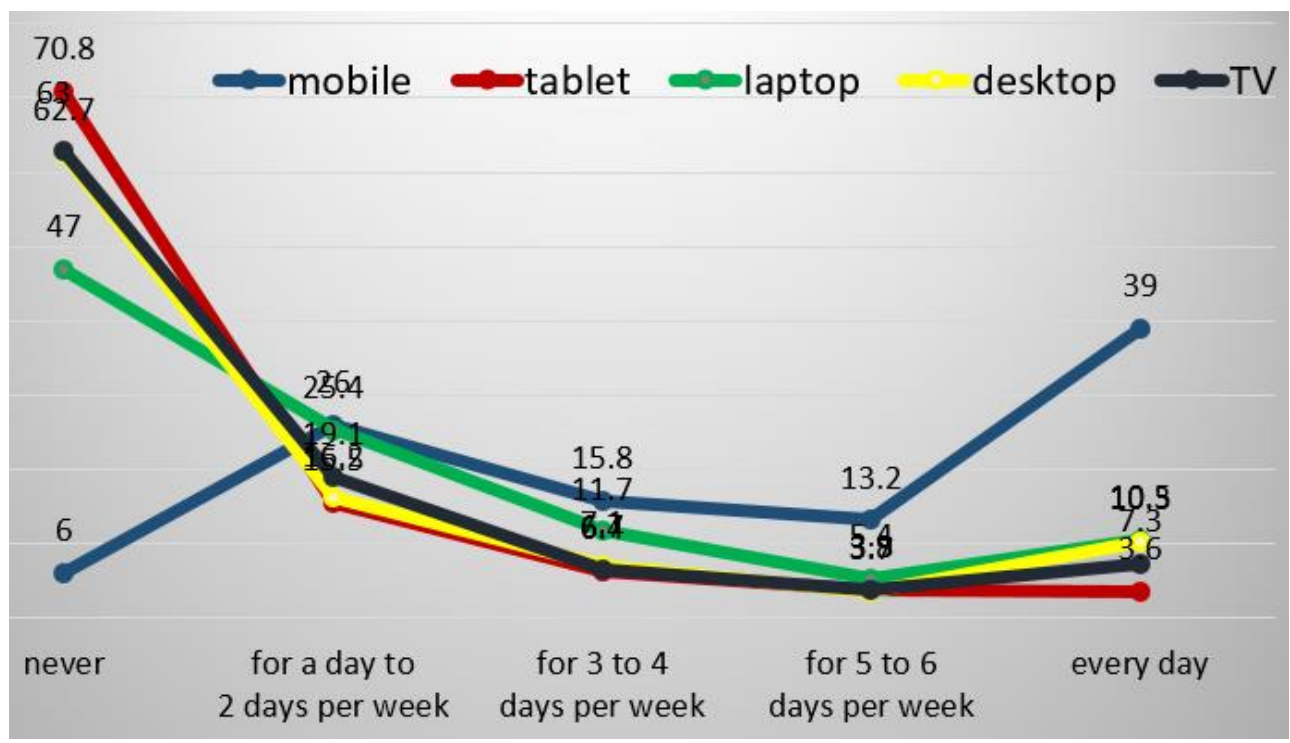

Graph 4. The Relationship between the Tool whereby Generation Z Secondary School Students accessed YouTube and the Frequencies of their Weekly Use.

When all graphs are considered, it is seen that the secondary school students accessed YouTube by means of a mobile device on each day of the week and by means of a mobile device $(80.1 \%)$ for up to 3 hours per day at the most. On the other hand, it is seen that the primary school students accessed YouTube by means of a television which could connect to the Internet for a day to 2 days per week and by means of a mobile phone for less than an hour per day.

The resulting picture reveals that the secondary school students used only one tool as their mobile phones were continually at hand, that they were freer as they could continually access their mobile communication devices, and that this led to an increase in the duration of YouTube use in terms of the weekly frequency and the daily duration, whereas the primary school students accessed YouTube by means of various devices (a television which could connect to the Internet in the case of weekly use but a mobile device in the case of daily use) at certain hour intervals. From this, it is possible to conclude that those at primary school accessed YouTube within the use durations provided by their parents.

Inferential analyses were made on the basis of the factors determined. These analyses were Correlation analyses.

There is a positive correlation between the grade level at which Generation Z primary school students studied and the factor "Using YouTube for social interaction" (rho=0.282; $\mathrm{p}=0.013$ ), and between the grade level at which Generation Z primary school students studied and the factor "The appeal of YouTube access speed" (rho=0.269; $\mathrm{p}=0.022$ ), and between the grade level at which Generation Z primary school students studied and the factor "Using YouTube to generate information" ( $\mathrm{rho}=0.240 ; \mathrm{p}=0.038$ ), and between the ages of Generation $\mathrm{Z}$ primary school students and the factor "Using YouTube for social interaction" (rho=0.250; $\mathrm{p}=0.028$ ) (Picture 3). 


\begin{tabular}{|l|l|l|l|l|l|l|l|l|l|l|l|l|}
\hline $\begin{array}{l}\text { The grade level at which } \\
\text { Generation Z primary school } \\
\text { students studied } \uparrow\end{array}$ & F1 & F2 & F3 & F4 & F5 & F6 & F7 & F8 & F9 & F10 & F11 & F12 \\
\hline $\begin{array}{l}\text { The ages of Generation Z } \\
\text { primary school students } \uparrow\end{array}$ & & & & & 个 & & & & & & & \\
\hline
\end{tabular}

Picture 3. The Relationships of the Grade Level at which Generation Z Primary School Students studied and their Ages with the Research Factors.

It is seen that the grade level at which the primary school students studied correlated with three motivation factors. This demonstrates that the primary school students carried on their offline relationships online too or that the grade in which they studied was important in their YouTube use motivations and that they were influenced by their friends in the classroom or their peers, i.e. that the state of being peers was important in YouTube use in terms of Generation Z. So, it turns out that the people to be considered examples online are important to the users who are improving and developing themselves within every scope, i.e. that the concept of opinion leader is important in terms of Generation Z.

According to the above-mentioned findings, the hypothesis "The most significant effect on the YouTube use motivations of the primary school students is the state of being peers." (Hypothesis 1) was accepted.

There is a positive correlation between the grade level at which Generation $\mathrm{Z}$ secondary school students studied and the factor "Using YouTube for publicity and self-actualization" $(\mathrm{rho}=0.172 ; \mathrm{p}=0.000)$ and between the grade level at which Generation Z secondary school students studied and the factor "Using YouTube to obtain economic utility" (rho=0.096; $\mathrm{p}=0.023)$.

There is a positive correlation between the ages of Generation Z secondary school students and the factor "Using YouTube for publicity and self-actualization" (rho=0.159; $\mathrm{p}=0.000$ ) and between the ages of Generation Z secondary school students and the factor "Using YouTube to obtain economic utility" (rho=0.083; $\mathrm{p}=0.048$ ).

There is a positive correlation between the YouTube use experience by Generation $\mathrm{Z}$ secondary school students and the factor "Using YouTube to reach information and alternative information" ( $\mathrm{rho}=0.097 ; \mathrm{p}=0.024)$, and between the YouTube use experience by Generation $\mathrm{Z}$ secondary school students and the factor "Using YouTube for educational purposes" (rho=0.088; $\mathrm{p}=0.042$ ), and between the YouTube use experience by Generation Z secondary school students and the factor "Using YouTube for self-expression by leaving comments" (rho=0.134; p=0.002), between the YouTube use experience by Generation Z secondary school students and the factor "Using YouTube to encourage purchasing" $(\mathrm{rho}=0.124 ; \mathrm{p}=0.004)$. There is a negative correlation between the YouTube use experience by Generation Z secondary school students and the factor "Using YouTube for publicity and self-actualization" (rho=-0.103; $\mathrm{p}=0.017$ ).

There is a positive correlation between the number of channels Generation $\mathrm{Z}$ secondary school students followed on YouTube and the factor "Using YouTube to reach information 
and alternative information" (rho=0.184; $\mathrm{p}=0.000$ ), and between the number of channels Generation Z secondary school students followed on YouTube and the factor "Using YouTube to obtain economic utility" (rho=0.126; $\mathrm{p}=0.013$ ), and between the number of channels Generation $Z$ secondary school students followed on YouTube and the factor "Using YouTube for socialization and social interaction" (rho=0.120; $\mathrm{p}=0.018$ ), and between the number of channels Generation $Z$ secondary school students followed on YouTube and the factor "Using YouTube for self-expression by leaving comments" (rho=0.167; p=0.001), and between the number of channels Generation Z secondary school students followed on YouTube and the factor "Using YouTube to encourage purchasing" (rho=0.130; $\mathrm{p}=0.010)$, and between the number of channels Generation Z secondary school students followed on YouTube and the factor "the appeal of YouTube access speed" (rho=0.171; $\mathrm{p}=0.001$ ), and between the number of channels Generation $Z$ secondary school students followed on YouTube and the factor "Using YouTube for entertainment" (rho=0.136; $p=0.007$ ).

There is a positive correlation between the number of available followers at the respective channels of Generation Z secondary school students on YouTube and the factor "Using YouTube for publicity and self-actualization" (rho=0.194; $\mathrm{p}=0.049$ ), and between the number of available followers at the respective channels of Generation $\mathrm{Z}$ secondary school students on YouTube and the factor "Using YouTube for socialization and social interaction" (rho=0.215; $\mathrm{p}=0.029)$ (Picture 4).

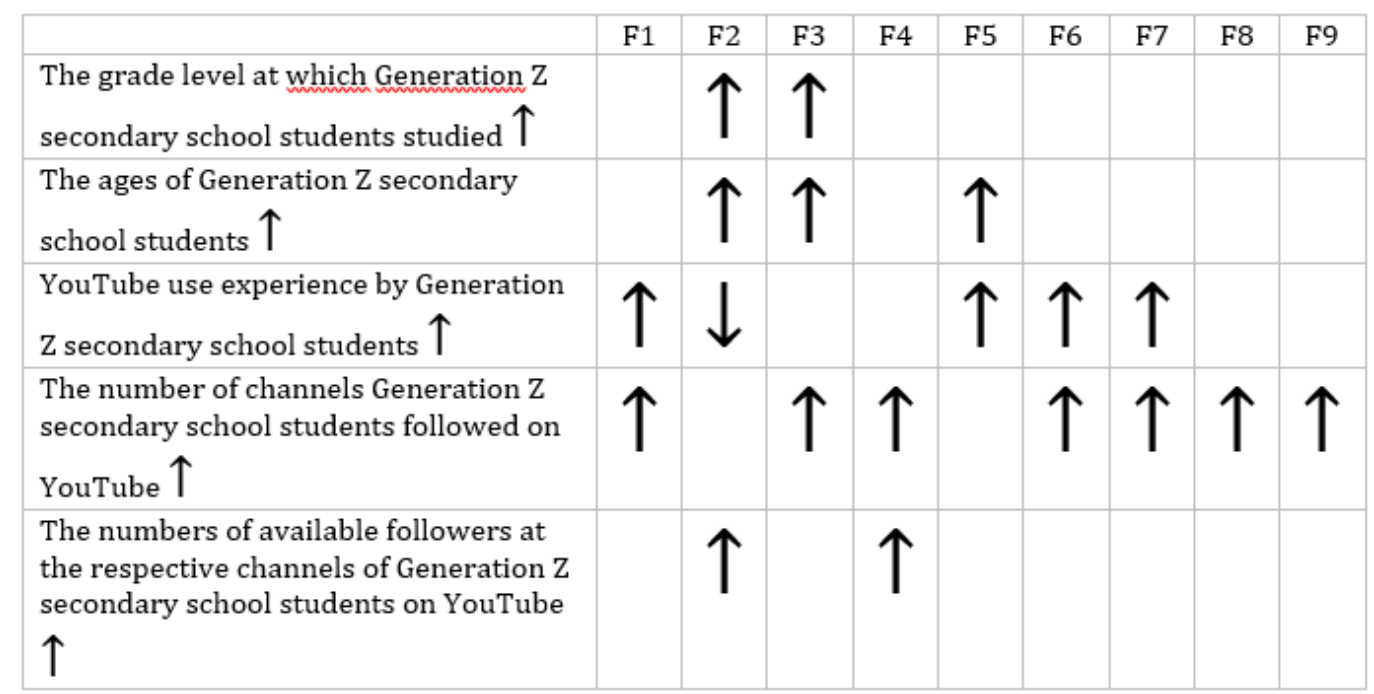

Picture 4. The Relationships of the Grade Level at which Generation Z Secondary School Students studied, their Ages, Users' YouTube Use Experience, the Number of Channels they followed on YouTube and the Number of Available Followers at their Respective Channels on YouTube with the Research Factors.

When the motivations of the primary and secondary school students and their demographic use characteristics are analyzed comparatively, it is seen that there are only four relationships between the demographic use characteristics of the users at primary school and their motivations (Picture 3). On the other hand, it is seen that this figure is greater in secondary education (nineteen relationships were detected; Picture 4). It is predicted that the small number of motivation relationships of the primary school students results from users' unconscious use owing to their ages. The ages of the secondary school students are greater 
than those of the primary school students, which indicates that they have a more conscious use motivation within the scope of YouTube owing to their ages. Briefly, it is seen that the primary school students performed their YouTube use motivations more unconsciously than the secondary school students. This reveals how important digital media literacy is in terms of primary school students and that one should concentrate on digital media literacy.

According to the above-mentioned findings, the hypothesis "Digital media literacy is important for Generation Z primary school students." (Hypothesis 2) was accepted.

\section{Conclusion}

The groups that were born in a certain time range and that have common values and behaviors under the influence of common social, cultural, political, and economic events are called generations. The YouTube use habits and motivations of the students born in and after 2000, called Generation Z, and aged between 7 and 18 years were examined in our research. According to the data of 2018 by the TUIK, there are about 25 million people of Generation $Z$ in our country. This shows that Generation $\mathrm{Z}$ make up more than one-third of the population in the country. Generation $Z$, who are more equipped than the other generations in educational and economic terms, spend the majority of their time online as they were born into a world where digital high technology was widely used and it is seen that they prefer interacting continuously.

In the research, the students aged between 7 and 18 years were taken as the sample as being representative of Generation Z; however, the sample group was divided into two as primary school students and secondary school students since they were affected differently by the written and visual contents offered to them according to the developmental qualities of children and teenagers. The students aged between 7 and 13 years make up the primary school students, while the students aged between 14 and 18 years make up the secondary school students.

As the most significant result of the research, made on the group influenced by common social, cultural, and economic events and called Generation Z, it turned out that the YouTube use motivations of the primary and secondary school students differed from each other. This demonstrates that digital technology and social media use motivations may change even in the case of a short age difference like 5 to 10 years and that when a targeting-based study on a mass of young people like Generation $\mathrm{Z}$ is carried out, the age ranges of the sample groups should hence be closer to each other.

The second significant result is that Generation $\mathrm{Z}$ users differed according to the tools whereby they accessed YouTube weekly and daily. The resulting picture demonstrates that the secondary school students were freer about using the social media since they predominantly used mobile phones only and were able to access continuously and that this gave rise to an increase in the weekly and daily use of YouTube, whereas the primary school students accessed YouTube by means of various devices (by means of a television which could connect to the Internet in the case of weekly use but by means of a mobile device in the case of daily use) at certain hour intervals. This shows that the majority of the primary school students accessed YouTube with parental mediation. 
The third significant result is that the state of being peers is important in terms of the YouTube use motivations of Generation $\mathrm{Z}$ users at primary school. The relationship of the grade level at which the primary school students studied, i.e. their state of being peers, with three YouTube use motivations shows that the primary school students carried on their offline relationships online too or that the grade in which they studied was important in their YouTube use motivations, that they were influenced by the class, and that the state of being peers at school was important to them. So, it is seen that the people to be considered examples online are important to the users who are improving and developing themselves within every scope, i.e. that the concept of opinion leader is important in terms of Generation Z. Similar results were also reached in the research performed with more than 12 thousand students going to high schools and post-high schools in 17 countries worldwide between August and September 2018 for DellEMC (2019). According to the report published with the title "Results of the Research on Generation Z for Turkey", Generation Z generally prefer getting recommendations from different groups when they need to do something for the first time. Whilst they consult parents or older people in England, they trust their friends in France. In Turkey, however, Generation Z state that they prefer YouTube videos as the first source to consult.

The fourth significant result is that digital media literacy is important for Generation $\mathrm{Z}$ users. When the motivations of the primary and secondary school students and their demographic use characteristics are analyzed comparatively, it is seen that the number of relationships between the demographic use characteristics of the users at primary school and the motivations was very small. On the other hand, this figure was greater in secondary education. It is predicted that the small number of motivation relationships of the primary school students results from users' unconscious use owing to their ages. It might be stated that as a result of the older ages of the secondary school students than those of the primary school students, they performed more conscious use on YouTube. This reveals the importance of digital media literacy in terms of primary school students and that one should concentrate on training about digital media literacy.

Another significant result is that since it is thought that the skill of using different media simultaneously - acquired at young ages - will continue at advanced ages too, one should concentrate on practices concerning the multi-screen skill in the communication studies to be carried out.

\section{References}

Adıgüzel, O., Batur, H. Z. \& Ekşili, N. (2014). Kuşakların Değişen Yüzü ve Y Kuşağı ile Ortaya Çıkan Yeni Çalışma Tarzı: Mobil Yakalılar. Journal of Süleyman Demirel University Institute of Social Sciences, 1(19), 165-182.

Akdemir, A., Konakay, G., Demirkaya, H., Noyan, A., Demir, B., A $\breve{g}$, C., Pehlivan, Ç., Özdemir, E., Akduman, G., Eregez, H., Öztürk, İ. ve Balcı, O. (2013). Y Kuşağının Kariyer Algısı, Kariyer Değişimi ve Liderlik Tarzı Beklentilerinin Araştırılması. Muğla Sıtkı Koçman University Faculty of Economics and Administrative Sciences Journal of Economics and Management Research, 2(2), 11-42. 
Akyazı, E. \& Ünal, A. T. (2013). İletişim Fakültesi Öğrencilerinin Amaç, Benimseme, Yalnızlık Düzeyi İlişkisi Bağlamında Sosyal Ağları Kullanımı. Global Media Journal Turkish Edition, 6(3), 1-24.

Altuntuğ, N. (2012). Kuşaktan Kuşağa Tüketim Olgusu ve Geleceğin Tüketici Profili. Journal of Organization and Management Sciences, 4(1), 203-212.

Arslan, A. \& Staub, S. (2015). Kuşak Teorisi ve İçgirişimcilik Üzerine Bir Araştırma. Kafkas University Journal of Economics and Administrative Sciences Faculty, 6(11), 1-24.

BBC. (2018). Facebook'tan Soğuyan Amerikan Gençliği, YouTube, Instagram ve Snapchat'e Yöneldi. https://www.bbc.com/turkce/haberler-dunya-44327963 Access: 10.12.2018.

Bento, M., Martinez, L. M. \& Martinez, L. F. (2018). Brand Engagement and Search for Brands on Social Media: Comparing Generations $\mathrm{X}$ and $\mathrm{Y}$ in Portugal. Journal of Retailing and Consumer Services, 43, 234-241.

Bonander, A.R \& Marsh, M.L. (2015) Modern Mimicry and YouTube: How Technology Has Influenced Pedagogy and Performance of Poetry Interpretation Within Competitive Forensics. Communication Studies, 66(4), 448-457.

Çetin, C. \& Karalar, S. (2016). X, Y ve Z Kuşağ1 Öğrencilerinin Çok Yönlü ve Sınırsız Kariyer Algıları Üzerine Bir Araştırma. Journal of Administrative Sciences. 14(28), 157-197.

Çetin, M. \& Bel, A. (2014). Geleneksel Medya Gündeminin Belirlenmesinde Sosyal Medyanın Rolü. İletişim Kuram ve Araştırma Dergisi, 38, 55-72.

Çomu, T. (2012). Video Paylaşım Ağlarında Nefret Söylemi: Youtube Örneği. (Ankara University Institute of social Sciences Department of Women's Studies Master's Thesis, Ankara). https://tez.yok.gov.tr/UlusalTezMerkezi/TezGoster?key=RYan9_S-

Z7Eir3xdWGXBiMSMeQ_SNdyvuR7qfFEtQZATzhapUDVh5gRVq5kC_hH4 Access: 10.12.2018.

Çubukcu, A. \& Bayzan, Ş. (2013). Türkiye'de Dijital Vatandaşlık Algısı ve Bu Algıyı İnternetin Bilinçli, Güvenli ve Etkin Kullanımı ile Artırma Yöntemleri. Middle Eastern \& African Journal of Educational Research, 5, 148-174.

DellEMC. (2019). Z Kuşă̆ı Türkiye Araştırması Sonuçları. https://blog.dellemc.com/tr-tr/zkusagi-turkiye-arastirma-sonuclari/ Access: 24.01.2019.

Eshleman, J.R. \& Bullcroft, R. (2009). The Family. 12th edition, NJ: Prentice Hall.

Gurău, C. (2012). A Life-Stage Analysis of Consumer Loyalty Profile: Comparing Generation X and Millennial Consumers. Journal of Consumer Marketing, 29(2), 103-113.

Inglehart, R.F. (2008). Changing Values Among Western Publics From 1970 To 2006. West European Politics, 31(1-2), 130-146.

Issa, T. \& Isaias, P. (2016). Internet Factors Influencing Generations $\mathrm{Y}$ and $\mathrm{Z}$ in Australia and Portugal: A Practical Study. Information Processing \& Management, 52(4), 592-617.

Karahasan, F. (2018). Açılın Gençler Geliyor: Y ve Z Nesilleri Nasıl Bir Dünya Kuracak? Türkiye'de ve Dünyada Gençler Ne Düşünüyor, Ne Bekliyor, Neyi Hayal Ediyorlar? İstanbul: Doğan Egmont Yayıncilik. 
Karahisar, T. (2013). Dijital Nesil, Dijital İletişim ve Dijitalleşen (!) Türkçe. AJIT-e: Online Academic Journal of Information Technology, 4(12), 71-83.

Keleş, H.N. (2011). Y Kuşağı Çalışanlarının Motivasyon Profillerinin Belirlenmesine Yönelik Bir Araştırma. Journal of Organization and Management Sciences, 3(2), 129-139.

Klobas, J.E., McGill, T.J., Moghavvemi, S. \& Paramanathan, T. (2018). Compulsive YouTube Usage: A comparison of Use Motivation and Personality Effects. Computers in Human Behavior, 87, 129-139.

Kraljević, R. \& Filipović, Z. (2017). Gender Differences and Consumer Behavior of Millennials. Acta Economica Et Turistica, 3(1), 5-13.

Kuyucu, M. (2017). Y Kuşağı ve Teknoloji: Y Kuşağının İletişim Teknolojilerini Kullanım Alışkanlıkları. Gümüşshane University e-journal of Faculty of Communication, 5(2), 845-872.

Lissitsa, S. \& Kol, O. (2016). Generation X vs. Generation Y-A Decade of Online Shopping. Journal of Retailing and Consumer Services, 31, 304-312.

Lower, J. (2008). Brace Yourself Here Comes Generation Y. Critical Care Nurse, 28(5), 80-84.

Mannheim, K. (1952) The Problem of Generations Essays on the Sociology of Knowlegde. Routledge, London. http://www.history.ucsb.edu/faculty/marcuse/classes/201/articles/27MannheimGeneration s.pdf Access: 10.12.2018.

Mercimek, B., Yaman, N. D., Kelek, A. \& Odabaşı, H. F. (2016). Dijital Dünyanın Yeni Gerçeği: Troller. Trakya University Journal of Education, 6(1), 67-77.

Metin, S. \& Kızıldağ, D. (2017). X Ve Y Kuşaklarının Kariyer Beklentilerinin Farklılaşması: Otomotiv Sektöründe Bir Araştırma. Mustafa Kemal University Journal of Social Sciences Institute, 14(40), 340-363.

Moss, S. (2010). Generational Cohort Theory. https://www.sicotests.com/psyarticle.asp?id=374 Access: 15.12.2018.

Özdemir, Ş. (2017). Kuşaklar Teorisine Göre Türkiye'deki Gençlerin Medya Kullanım Alışkanlıkları ve İstanbul Örneği . (Marmara University Institute of Social Sciences. Unpublished Master's Thesis, İstanbul). http://tez2.yok.gov.tr/ Acess: 10.12.2018

Özmen, E. (2018). Sosyal Medya ve Modanın Dijitalleşmesi Arasındaki İlişkiyi Tanımlamaya Yönelik Bir Durum Çalışması: Y Kuşağı Örneği. Akdeniz University Journal of Communication Faculty, 29, 128-150.

Priporas, C.-V., Stylos, N. \& Fotiadis, A. K. (2017). Generation Z Consumers' Expectations of Interactions in Smart Retailing: A Future Agenda. Computers in Human Behavior, 77, 374381.

Quintal, V., Phau, I., Sims, D. \& Cheah. I. (2016). Factors Influencing Generation Y's Purchase Intentions of Prototypical Versus Me-Too Brands. Journal of Retailing and Consumer Services, 30, 175-183.

Sarsar, F. \& Engin, G. (2015). Sınıf Öğretmeni Adaylarının Medya Okur-Yazarlık Düzeylerinin İncelenmesi. Ege Journal of Education, 16(1), 165-176. 
Somyürek, S. (2014). Öğretim Sürecinde Z Kuşağının Dikkatini Çekme: Artırılmış Gerçeklik. Education Technology Theory and Practice, 4(1), 63-80.

Strauss, W. \& Howe, N. (1991). Generations: The History of America's Future, 1584 to 2069. New York: William Morrow and Company Inc. https://archive.org/details/GenerationsTheHistoryOfAmericasFuture1584To2069ByWillia mStraussNeilHowe Access: 17.12.2018.

Taş, H. Y., Demirdöğmez, M. \& Küçükoğlu, M. (2017). Geleceğimiz Olan Z Kuşağının Çalışma Hayatına Muhtemel Etkileri. OPUS International Journal of Society Researches, 7(13), 1031-1048.

Taylor, J. C. (2008). Whither March the Cohorts: The Validity of Generation Theory as a Determinant of the Sociocultural Values of Canadian Forces Personnel. Toronto: Canadian Forces College National Security Studies Program. https://www.cfc.forces.gc.ca/259/281/280/taylor.pdf Access: 10.12.2018.

TDK, (2018). www.tdk.gov.tr. Access: 10.12.2018.

Thorson, K., Driscoll, K., Ekdale, B., Edgerly, S.,Thompson L. G., Schrock, A., Swartz, L., Vraga, E. K. \& Wells, C. (2013). YouTube, Twitter And The Occupy Movement, Information. Communication \& Society, 16(3), 421-451.

Tunçalp, B. (2017). Ezber Bozan Yeni Nesil: Z Kuşă̆ı. Dijital Medya ve Çocuk. İstanbul Bilgi University Faculty of Communication. https://dijitalmedyavecocuk.bilgi.edu.tr/2017/11/14/ezber-bozan-yeni-nesil-z-kusagi/ Access: 10.12.2018.

Turner, A. (2015). Generation Z: Technology and Social Interest. The Journal of Individual Psychology, 71(2), 103-113.

Türk, A. (2013). Değişimi Değgiştiren Geleceği Dönüştüren Y Kuşă̆g. İstanbul: Kafekültür Yayıncilik.

Yelkikalan, N., Akatay, A. \& Altın, E. (2010). Yeni Girişimcilik Modeli ve Yeni Nesil Girişimci Profili: İnternet Girişimciliği ve $\mathrm{Y}, \mathrm{M}, \mathrm{Z}$ Kuşağ 1 Girişimci. The Journal of Social Economic Research, 10(20), 489-506. 